\title{
Kristien Suenens, Humble Women, Powerful Nuns. A Female Struggle for Autonomy in a Men's
}

Church (Leuven: Leuven University Press, 2020, 384 Pp., ISBN 9789462702271 ).

Vrouwen speelden in België een opmerkelijke rol in het religieuze reveil van de negentiende eeuw (circa 1830-1860) en het ultramontaans katholicisme dat erop volgde. Niet alleen groeide het aantal religieuze initiatieven opgericht door en voor vrouwen spectaculair, ook speelden vrouwen een centrale rol in een postrevolutionaire katholieke kerk die zich meer richtte op sociale, caritatieve en educatieve doelstellingen. Toch duurde het tot de jaren 1980 vooraleer historici, onder invloed van onderzoek naar gender, meer aandacht besteedden aan de maatschappelijke positie van religieuze vrouwen in de negentiende eeuw. Zeker recentere literatuur kent een inhaalbeweging op dit vlak, maar het onderzoek naar Belgische religieuze vrouwen blijft desalniettemin beperkt.

Door specifiek te focussen op een Belgische casus, levert Kristien Suenens met Humble Women, Powerful Nuns een belangrijke bijdrage aan het onderzoek naar deze onderbelichte groep. Meer specifiek stelt Suenens haar lens scherp op de maatschappelijke niche van vrouwelijke congregatiestichtsters en -leidsters in de Belgische romantische en ultramontaanse kerk uit de periode $1820-1885$ en bestudeert ze welke agency deze vrouwen hadden binnen de limieten van deze niche. De auteur definieert agency hierbij niet als het actief uitdagen van de dominante machtsstructuren, maar als 'the ability to act or perform, consiously or not, within the boundaries of these traditional structures' (25).

De studie zelf is een groepsportret van vier congregatiestichtsters: Anna de Meeûs, Fanny Kestre, Antoinette Cornet en Wilhelmina Telghuys. Allen richtten ze een eigen congregatie op in het aartsbisdom Mechelen in de laatste decennia van de religieuze heropleving, een periode die zich kenmerkt door een spectaculaire groei van apostolisch geïnspireerde kloosters. Hun congregaties kwamen vervolgens tot volle wasdom in een meer combattieve, ultramontaanse kerk. Hoewel de besproken vrouwen voor gelijkaardige maatschappelijke veranderingen en uitdagingen stonden, bevatten hun levensverhalen ook voldoende verschillen. Waar Telghuys en de Meeûs van rijke komaf waren, behoorden Kestre en Cornet tot de middenklasse. Ook hun congregaties hadden een andere finaliteit. De Soeurs du Saint-Coeur de Marie van Cornet was een onderwijscongregatie, terwijl Telghuys, die de Dienstmaagden van de Heilige Harten van Jezus en Maria heeft opgericht, naast onderwijs voor wezen ook een semi-industriële wasserij uitbaatte. Kestre richtte zich met haar congregatie Dames de Sainte-Julienne-Apostolines du 
Très Saint-Sacrement op apostolisch geïnspireerd religieus onderwijs, net als de Meeûs, maar haar semi-contemplatieve congregatie, Institut de l'Adoration perpétuelle, had een internationaal bereik en een meer elitair karakter.

Het boek is opgedeeld in drie delen. Het eerste deel focust op de periode van circa 1820 tot 1860 en behandelt de wijze waarop de vrouwen hun eerste religieuze en sociale initiatieven opzetten in een romantische kerk die haar plaats zocht in de postrevolutionaire maatschappij. Het tweede deel richt zich op de eigenlijke stichting van de congregaties in de nadagen van de religieuze heropleving (1857-1867). In het laatste deel gaat Suenens nader in op de periode $1865-1885$ en focust ze op de consolidatie van de congregaties tegen de achtergrond van de cultuuroorlog tussen katholieken en liberalen, en van een militante ultramontaanse kerk die actief streefde naar het primaat van de kerk. Suenens sluit af met een epiloog waarin ze het (beperkte) Nachleben van de vier vrouwen bespreekt.

In haar analyse maakt de auteur gebruik van het methodologisch concept van double-voiced discours. Hiermee verwijst ze naar de strategie van de vrouwen om zich in te passen in de bestaande machtsstructuren, maar daarbij (al dan niet bewust) ruimte voor hun eigen agency schiepen door zich het bijhorende discours toe te eigenen (26). Suenens schrijft: 'In order to exist and survive women had no choice but to express themselves in the dominant language of men, often confirming female docility, passivity and subordination. However women did integrate echoes of another, sometimes opposing "muted voice" of female agency into their apparently conformist writings' (24). Ze gaat op zoek naar de gesmoorde stem van de vier bestudeerde congregatieleidsters in de teksten die de vrouwen zelf schreven en die over hen geschreven werden. De auteur maakt hierbij gebruik van een gevarieerd corpus aan egodocumenten zoals brieven, en spirituele en autobiografische notities van de besproken vrouwen. Dit bronnenmateriaal stelt ze tegenover andere archivalische bronnen, zoals gewoonteboeken, kronieken en rapporten, en economische bronnen, eveneens bewaard in de kloosterarchieven. Dit rijke corpus werd waar mogelijk uitgebreid met bronnen uit familiearchieven en archieven van andere religieuze instellingen, zoals die van de Jezuïeten en Redemptoristen, en diocesen die relaties met de vier congregaties onderhielden. Dit stelt de auteur in staat om op een comparatieve en fijnmazige manier de gesmoorde stemmen van de vier bestudeerde vrouwen naar voren te brengen.

Suenens toont overtuigend aan hoe de vier vrouwen het dominante narratief van vrouwelijke nederigheid bewust gebruikten om de mannelijke religieuze elite en aristocratische lekenschenkers aan te sturen en hun doelstellingen te realiseren. Het succes van hun congregaties hing met andere woorden samen met de mate waarin de vrouwen dit double-voiced discours beheersten. Ook andere factoren waren van belang: hun karakter, maar ook en vooral hun sociaaleconomisch kapitaal en hun netwerk. Dit wordt duidelijk in de vergelijking tussen Kestre en de Meeûs, die ook regelmatig aan bod komt in 
de studie. De rijke bourgeois-dochter de Meeûs, die goede connecties had met de elite en zich het nederigheidsdiscours eigen had gemaakt, slaagde er vaker in haar ambities te realiseren dan Kestre, die lager op de sociaaleconomische ladder stond, het netwerk van de Meeûs mankeerde, maar ook vaker de nederigheid in haar discours liet vallen om assertiever naar voren te treden.

Een belangrijke conclusie die de auteur naar voren schuift, is dat de agency van de vier besproken vrouwen niet leidde tot of deel uitmaakte van een breder netwerk van vrouwelijke solidariteit. Vaak was er bittere concurrentie tussen congregatieleidsters. Bovendien hielden hun activiteiten niet altijd een verbetering in van de positie van hun leden. De vier vrouwen maakten deel uit van een eng bepaalde sociale niche, een 'hortus conclusus' (343), die opwaartse mobiliteit bood aan wie beschikte over het nodige economische kapitaal, het netwerk en de vaardigheden. Een double-voiced discours stelde hen in staat om de lacunes in de machtsstructuren uit te buiten, maar zo bevestigden en versterken ze wel het beeld van nederige vrouwen. Het resultaat is een uiterst paradoxaal en ambigu beeld. De auteur sluit hiermee aan bij onderzoek naar religieuze vrouwen in andere perioden, want ook voor de premoderne context benadrukken analyses in toenemende mate de diversiteit en ambiguïteit van het vrouwelijke kloosterleven. ${ }^{1}$ Het lijkt erop dat studie naar nonnen, zoals de auteur beargumenteert, in de eerste plaats een studie naar ambiguïteit is.

Suenens levert met Humble Women, Powerful Nuns een innovatieve bijdrage aan het onderzoek naar de maatschappelijke positie van vrouwelijke congregatieleiders in negentiende-eeuws België en werpt een nieuw licht op een lang genegeerd onderwerp. Het boek is goed en vlot geschreven, en is doorspekt met citaten uit een gevarieerd bronnencorpus. Hoewel het werk door zijn opzet veel biografische gegevens en relaties tussen netwerken bevat, verzandt Suenens niet in biografische feitelijkheid door de vrouwen onderling voldoende te vergelijken. Een bijkomende meerwaarde is de aandacht die de auteur besteedt aan de relaties van Kestre, de Meeûs, Cornet en Telghuys met het mannelijke klerikale establishment, aristocratische lekenschenkers en andere religieuze vrouwen in binnen- en buitenland. Humble Women, Powerful Nuns is daarmee een gedegen comparatief onderbouwde studie die de complexe maatschappelijke rol van vrouwelijke religieuzen in de negentiende eeuw kadert.

Jirki Thibaut 